\title{
CREATIVITY AS THE MAIN DETERMINANT OF IMPLEMENTING FRUGAL INNOVATIONS IN ENTERPRISES ${ }^{1}$
}

\author{
Roman TYLŻANOWSKI \\ Wydział Ekonomii, Finansów i Zarządzania, Uniwersytet Szczeciński; roman.tylzanowski@usz.edu.pl, \\ ORCID: 0000-0003-3644-1935
}

Purpose: The article aims to define the role that creativity plays in implementing frugal innovations. The article also aims to list examples of innovative, frugal solutions as well as to indicate activities that would stimulate the creativity of employees in enterprises.

Design/methodology/approach: This is an exploratory study that is based on a systematic review of available literature on frugal innovation and creativity. The research was based on both Polish and foreign literature, articles, and internet sources.

Findings: The issue of frugal innovations has recently become "fashionable" in the good sense of the word. Inventive and cheap offers of products and technologies launched on markets are characterised by demonstrable dynamics. The article emphasises, in particular, the role of creativity in creating innovative, frugal solutions.

Research limitations/implications: Although the problem of frugal innovations is known and described, it is also true that publications focussing on and discussing this issue are still lacking. The article, therefore, aims to encourage decision-makers to support the creativity of their employees in order to develop frugal innovations. Nevertheless, the discussed topic requires further research.

Originality/value: The article is based on existing knowledge in the field of creativity and frugal innovations. The added value of the article is a combination of both issues, emphasising the role of employees' creativity in creating frugal innovations, which is illustrated in the form of the proposed model of the innovative process based on creativity.

Keywords: creativity, innovation, frugal innovations, determinants, innovation process.

Category of the paper: Conceptual paper.

\footnotetext{
${ }^{1}$ Project financed under the program of the Minister of Science and Higher Education under the name "Regional Initiative of Excellence" in the years 2019-2022 project number 001/RID/2018/19 funding amount 10684000.00 .
} 


\section{Introduction}

Innovations are invariably one of the most important factors in the development of modern enterprises and the economy as a whole. Their ultimate goal is to create new concepts and to move away from traditional solutions. Initiating, acquiring, and implementing innovations contributes to increasing the competitiveness of enterprises. Companies willing to take innovative actions also strengthen the international position of individual countries.

It seems that innovations have become an inseparable businesses aspect of every enterprise. In order to deal with the dynamic economic changes, to constantly meet market needs, and to achieve and maintain a competitive edge, modern organisations are compelled to implement them. This is also confirmed by the approach "sustainability enterprise" in which one of the paradigms, apart from knowledge, trust, and entrepreneurship combined with organisational culture, is innovation (Grudzewski, Hejduk, Sankowska, Wańtuchowicz, 2010, p. 13). In turn, the innovative activity of enterprises is considered to be one of the most important factors in the development of a modern economy. Terms such as the smart economy (Intelligent Economies..., 2018), sustainable economy (Bontoux, Bengtsson, 2015), knowledge-based economy (OECD, 1999) economy 4.0 (Kaz, Ilina, Medvedev, 2019) describe economic systems that are driven by innovations. Therefore, all considerations concerning innovations as well as their specificity and types, which are characteristic of contemporary economic challenges, constitute an important scientific discourse in the field of management sciences.

Of course, the process of creating and implementing innovations also involves a high risk of failure. This is mainly because this process usually requires high financial outlays, and the obtained results may be noticeable only over a longer time span. For traditionally understood innovations, time is not an ally, therefore, the ability to react to changes continuously and with flexibility in the economy, and to quickly implement innovative solutions, becomes useful. While 30 years ago it took an average of 6 years to develop a new car model, today the process is three times shorter. The Hewlett-Packard company also confirms the crucial role of time in implementing innovations. Currently, most of the company's revenue comes from products that did not exist the previous year (Bencsik, Machová, Tóth, 2016, p. 85). The necessity to react quickly to rapid economic changes, as well as other challenges such as issues related to sustainable development, including environmental protection, force us to search for forms of innovation that will be able to deal with various aspects of the economic reality that surrounds us. Such a group of innovations undoubtedly includes frugal innovations, which are known and described but publications focussing on and discussing this issue are still lacking. 


\section{The importance of frugal innovations in a modern economy}

Due to the increasing pace of changes, the increase in ties with the environment, limited budgets, restricted resources, and growing diversity, enterprises more and more often seek out and decide to introduce innovations that do not absorb significant financial resources. In addition, modern companies do anything to combine their activities with sustainable development. In the field of innovation, the trend that has helped many companies from the East to succeed is playing an increasingly important role (Bencsik, Machová, Tóth, 2016, p. 88); the so-called frugal innovations.

„Frugal innovations refer to products, processes or marketing and organisational methods that aim to minimise the consumption of material and financial resources while meeting or even exceeding predefined criteria of acceptable quality standards" (Tiwari, Herstatt, 2012, p. 4). As indicated by Radjou and Prabhu (2014, p. 12), as opposed to creating completely new or improved products or processes, which is the paramount goal of innovative activity in the traditional sense, the frugal approach involves revising existing solutions in order to provide more business and social value by minimising the use of resources.

These innovations are usually developed with great resource constraints and consist of good quality goods or services that are sold at reasonable prices. As a consequence, even middleclass or lower-class people can afford them. In other words, frugal innovations are „sufficiently good, inexpensive products that meet the needs of resource-constrained consumers" (Zeschky, Widenmayer, Gassmann, 2011, pp. 38-45). Their initial target was countries with a low level of development, but markets in highly developed countries are increasingly opening up to them.

Frugal innovations are becoming a global trend, evoking a new and "healthy" view on the theory and practice of innovative processes. Simultaneously, it turns out that the organisations themselves contain large amounts of savings innovations, supported (stimulated) by a global phenomenon of shrinking resources and catastrophic climate visions. Thanks to frugal innovations, communities in a difficult economic situation are able to raise their standard of living and solve various problems, including those related to health, education, or energy. Thus, frugal innovations have a significant impact on the economy, solving numerous social problems by generating ideas and producing revenue from business (Khan 2016, p. 1). Therefore, the type of innovations under discussion seem to be of key importance for the development of enterprises and the entire economy, and will certainly play a crucial role in the coming years.

The idea of frugal innovations, which consolidate the interests of entrepreneurs and consumers while promoting a simultaneous positive impact on the natural environment, appears as an interesting alternative for purely innovative solutions. Turbulent times, including the ongoing global economic crisis, which has exposed weaknesses even in developed economies, together with the growing social stratification and the spectre of environmental destruction, 
constitute a significant challenge that requires a change in approach to various spheres of our lives, including the sphere of organisation management. Frugal innovations make it possible to face major problems in the global economy, creating economic and social value without harming the environment. For this reason, modern enterprises should consider the implementation of such solutions, and theorists should explore their specificity.

The basic criteria determining frugal innovations include significant cost reduction, focus on key functionalities, and optimised efficiency level. Importantly, the links between these three criteria are crucial. The mere reduction of costs, without revising the functionality of the product or service as well as the level of efficiency, cannot mean that a given change is a frugal innovation. Similarly, the mere improvement of a product, without reducing its function to the necessary functionality, cannot be considered a frugal innovation (Weyrauch, Herstatt, 2016).

The potential of frugal innovations is reflected in many dimensions, such as (A conceptual analysis..., 2016, pp. 11-12):

- local solutions aiming to meet the low demand threshold in less developed markets (e.g. water filter powered by a moped, solar bulb),

- local solutions related to the challenges of sustainable development in less developed markets (e.g. agricultural innovations),

- frugal product engineering and corporate "mass frugality" based on reducing functions and on affordability (e.g. Tata Nano car, costing just $\$ 2,000$ ),

- frugal product-related innovations, based on increasing utility through robustness and sustainability (e.g. Nokia 1100, Jaipur Foot),

- reduction of process costs, based on the use of developing market conditions and intelligent, low-cost production processes (e.g. an uncomplicated dashboard on a Dacia),

- $\quad$ solutions personalised en masse for less developed markets, based on cooperation with local partners (e.g. home appliances),

- standardised frugal solutions for less developed markets, based on the concept of personalised delivery (e.g. solar panel rental models),

- global transformational solutions based on the challenges initially identified in frugal environments (e.g. Skype, mobile banking).

The need to respond to changes in the environment is tested during the global crisis caused by the coronavirus pandemic. The temporary closure of borders and the slowdown in international trade have stimulated local innovativeness in new or even surprising ways. Below are some examples of frugal innovations (most often low-tech ones), which, thanks to the creative approach of their designers, have made it possible, for example, to effectively fight the pandemic (https://includeplatform.net/...): 
- local manufacture of hand sanitisers and soaps using locally available, affordable materials at the grassroots level,

- mechanical and automatic water and soap dispensers in public stations that use pedals or thermal sensors to minimise human contact with sanitisation equipment,

- manufacture of face masks using for instance, kitenge fabric and other locally available materials,

- PumuaIshi 2.0 - portable, robust, compact and economical ventilator that an be used by untrained medical personnel and can operate off grid for up to four hours,

- mobile phone-based e-health applications (e.g. applications that help individuals assess their COVID-19 risk category through a digital triage tool, run interactive COVID-19 FAQs via WhatsApp-based chatbots, and create public awareness through text messaging),

- Kisomo SmartLearn - application that runs a makeshift video recording studio that teachers from the region can use to deliver their content.

These examples show that in times of crisis, innovative undertakings should, above all, be robust, flexible, accessible, and affordable, taking into account the existing constraints and opportunities in terms of resources and infrastructure.

\section{The creativity of employees and its impact on the creation of innovative solutions}

In order to maintain or improve their competitive position in the market, enterprises should constantly strive to maintain the maximum level of informativeness, taking advantage of any new sources for this purpose (Chyba, 2014, p. 230). A number of different factors can affect the implementation of frugal innovations. They are usually dynamic in nature, therefore, their importance, from the point of view of an economic entity, may change over time and may depend on a variety of other conditions. Anything that can generate specific ideas, concepts, and projects, and can contribute to searching for and finding new things, or undertaking ventures as well as implementing and improving them, can be classified as sources of innovation (Penc, 1999, p. 157).

Sources of frugal innovations can be classified in many different ways. At the macroeconomic level, both domestic and foreign sources can be distinguished. This classification takes into account, among others, factors such as economic growth, the structure of unemployment and prices, market situations, fiscal and monetary policy as well as the legal system of a given country. In turn, at the microeconomic level, it is possible to distinguish internal (endogenous) and external (exogenous) conditions; external conditions may be domestic or foreign. The source of innovation is, therefore, everything that can inspire 
a person/enterprise to the process of change. The environment that stimulates changes and allows a reaction to the changing surroundings in a creative way is of key importance (Pomykalski, 2001, p. 34).

The word "creativity" is nowadays used to describe not only people (e.g. "creative attitude"), but also many objects, fields, or phenomena (e.g. "creative product", "creative sales", "creative accounting"). More than half a century ago, people were already pointing out that creativity is a process resulting in innovative and useful products, accepted by large groups of people and which ensures satisfaction from using them during a specific time (Stein, 1953, p. 312). According to Teresa Amabile (1998, pp. 77-78), who has conducted extensive research in this field, creativity is a set of several elements, being knowledge, motivation, competence, creative thinking skills, and organisational culture. It is also emphasised that creativity is the ability of people to create new and valuable creations (Szmidt, 2013, p. 22). Therefore, it is primarily a human trait that determines the generation of ideas, enabling the creation of new and better ones compared to the current solutions. Creativity can also be treated as a human skill that allows for ,a different perception of the world, creating new ideas, expressing knowledge and distinctness" (Szara, 2014, p. 201). Creative thinking is very often also defined as a person's personality disposition, which is distinguished by an unconventional approach to various problems and unusual ideas for solving them as well as a positive approach, learning from mistakes, and determination in taking innovative actions (Kaliszczak, 2013, p. 78). Such unconventional thinking and action are useful especially in difficult and critical moments, independent of the company.

Creativity is, of course, a necessary factor resulting in innovation. According to Kampylis and Berki (2014, p. 6) ,creative thinking should enable all people involved in innovative processes to use their imagination to generate ideas, questions, and hypotheses, experiment with alternatives, and evaluate their own and external ideas, end products, and processes". According to numerous authors from the field of management and quality sciences, creativity should be treated as the first stage of the innovation process, as a source of generating new concepts and ideas.

Two types of creativity can be distinguished: conceptual creativity related to the development of new methods, models, or theories, and operational creativity necessary in practical implementation processes and the verification of conceptual creativity products (Baruk, 2006, p. 90). It cannot be denied that creativity is especially useful when new ideas have a chance to find application in solutions that improve the functioning of a company (e.g. a new process leading to an increase in production capacity), as well as in products offered to its customers and the entire community (e.g. innovative goods and services that can be used by everyone, regardless of their level of wealth). Therefore, creativity should not be considered only in conceptual terms but should be treated primarily as a factor enabling the implementation of new and useful products so, it is imperative that creativity is at the centre of interest for all enterprises, not only those characterised by a high level of innovativeness. Creativity is nothing 
other than necessary when proposing and implementing cost-effective innovations because it is inventive and creative staff who are able to both propose modern, affordable, and sustainable solutions, and achieve them in a quick, efficient, and frugal manner.

\section{A model of the process for creating frugal innovations based on creativity}

Ensuring or maintaining a long-term competitive edge is becoming more and more difficult, which is a result, among other things, of the changing environment and constant competition from other entities. Strengthening the position of business entities is possible primarily thanks to focusing on the originality and uniqueness of the solutions created (products, processes, marketing, or organisational methods). Currently, business entities are looking for a way to continuously improve and develop solutions that will be characterised by high quality (uniqueness), but at the same time will not generate high costs. One of the most important resources that both initiates and leads to obtaining these effects is creative staff. Therefore, the crucial internal source of frugal innovations is creativity. A significant role of creativity in creating the value of an enterprise is seen in particular in entities characterised by a high level of innovativeness, whose products appearing on the market are not the result of incurring significant financial outlays. For such companies, what matters most is the human element, treated as the basic inexhaustible resource in which it is worth investing (Jung, 2010, p. 222), because it leads to a competitive edge for the enterprise.

When assessing the potential of innovations, it is worth quoting the arguments put forward by Radjou and Prabhu (2014). They argue that frugal innovations allow companies to introduce high-quality products to the market cheaper and faster while using a limited amount of resources. They also emphasise that good-quality products can be affordable and sustainable.

In the linear innovation process, based on the classical Schumpeter theory, the creation of innovation is preceded by research and development which consists of 3 phases: basic research, applied research, and development work (Francik, Kosała, 2011, p. 7). It turns out that in the case of frugal innovations, it is not at all necessary to incur high outlays on research and development activities. Entities that offer frugal innovations should pay particular attention to engagement and iteration (Radjou, Prabhu, 2014, pp. 1-18). The smaller role of research and development for this group of innovators results, among others, from the following premises (Radjou, Prabhu, 2014, pp. 1-18):

- Research and development are usually time-consuming and inflexible.

- They focus on the quality of the results itself, rather than the quality of the results in connection with their value to customers. 
- They are complex and costly. Moreover, their complexity is costly, both for the companies producing them and their customers.

- They are not environmentally friendly. For example, the complexity and short life cycle of mobile phones increase waste production.

- The role of customers is rather to approve the product idea/prototype than to co-create solutions.

Therefore, enterprises should work fast, involve end-users, focus on simple solutions, and use external resources, experts, and infrastructure, and reduce bureaucratic restrictions wherever possible. The basic and unlimited resource to which the enterprise has access is the creativity of the employees of the company. The author proposes a model of the process of creating frugal innovations based on creativity (fig. 1).

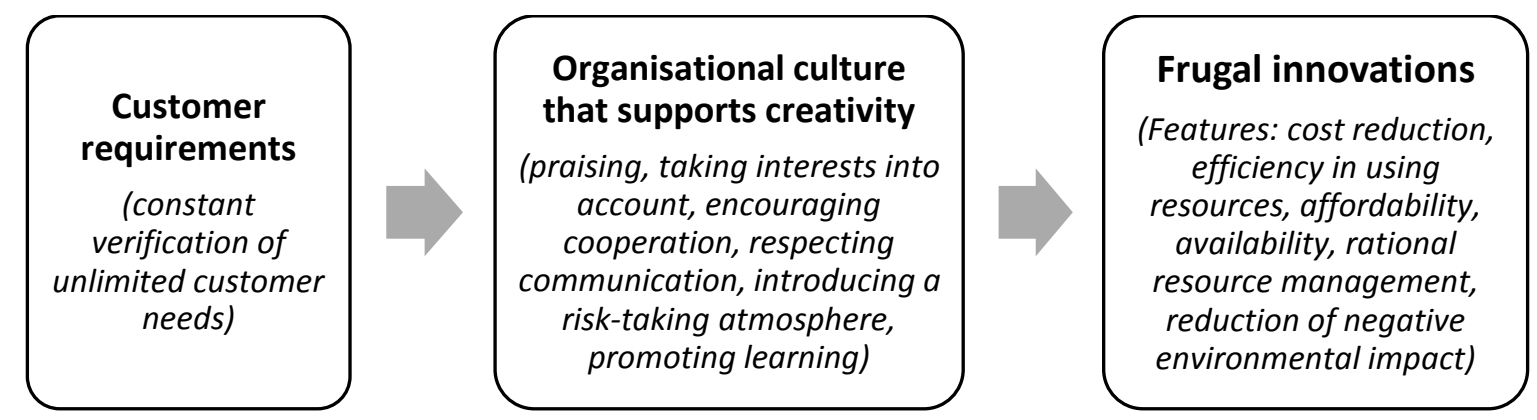

Figure 1. Model of the process of creating frugal innovations based on creativity. Source: Own elaboration.

As in the case of demand models of the innovation process, frugal innovations require, first of all, examining the needs/requirements of recipients. One of the most important sources of frugal innovations is the so-called "street", i.e. people with specific expectations or who are struggling with certain problems. The community can inspire people to develop new, frugal solutions. It should be remembered that innovativeness does not only mean generating creative ideas. We can speak of the effectiveness of innovative processes only when the proposed solutions are commercialised. Innovative products must arouse the interest of a specific group of buyers and be approved by them.

Enterprises differ from each other, e.g. in terms of production volume, assortment offer, level of innovativeness, or the number of employees. Each enterprise, irrespective of the aforementioned differences, should create appropriate conditions within the organisation for stimulating the creativity of its employees. Therefore, the basis for the creative and effective operation of enterprises seems to be an appropriate organisational culture. This constitutes a set of common values, goals, and beliefs of the company that determine the level of commitment as well as the method and quality of the work of all its employees (Armstrong, 1997, p. 115). Creating a favourable organisational culture in a company is not easy; the most important element is that companies implementing innovations (including the frugal ones) should learn from mistakes and draw conclusions for the future. Enterprises should realise that failure must 
be accepted and made to be a factor that strengthens the company, prompting it to seek new, innovative solutions (Bogdanienko, Haffer, Popławski, 2004, pp. 39-40).

The key task of the company's managers is to select the right people for each position, as well as to provide them with opportunities and conditions to use their potential creatively. As a result, employees will be able to find, adapt, implement, and disseminate new solutions that bring benefits, both individual and social (Bal-Woźniak, 2010, p. 258). The tasks of company managers should include ensuring that creativity and innovation are respected by each member of staff and treated as basic cultural norms which are an integral part of the company's strategy.

Providing employees with a creative work environment forces the company management to perform appropriate activities, such as (https://www.roberthalf.com/...):

- Praising people and their work - any employee would like their work to be recognised.

- Taking into account employee interests - employee interests can be a very valuable source of generating new ideas.

- Encouraging cooperation - employees may come up with many interesting ideas during discussions and joint meetings. They only need space for such meetings to be organised.

- Respecting communication - it is important for employees to receive clear and explicit messages from their superiors. Managers should define what they expect, what they are striving for, and provide all necessary information to their co-workers on an ongoing basis.

- Establishing a risk-taking atmosphere - supervisors should allow their employees to take intelligent risks. This may turn out to be one of the most effective ways to achieve market success.

- Supporting innovation - inspiration for new innovative ideas can be anything that surrounds us, not necessarily within a given company. Therefore, employees should be given the opportunity to seek inspiration in a variety of places.

- Promoting learning and teaching - a person who manages staff well is one who allows their employees to attend a variety of training courses and workshops. The effect of this permission will be the acquisition of new knowledge and an increase in the chances to use it, e.g. when proposing and implementing innovative [frugal] solutions.

The above factors emphasise the role of management in stimulating the creativity of their employees. It should be remembered that creativity in an enterprise is usually activated if there is a so-called creative atmosphere. Thanks to greater freedom in action, employees are willing to activate different, out-of-the-box thinking. The system of submitting applications by each employee of the company, which will increase the freedom of choosing and solving problems, may be useful in the efficient introduction of innovations to the enterprise (Bogdanienko, Haffer, Popławski, 2004, p. 43). This way of thinking and acting leads to benefits being acquired not only by the company but also by every employee who is additionally motivated to take further creative actions. 
Creative work becomes active wherever there is a favourable, positive atmosphere. Staff managers must be aware that not all innovation-oriented activities are a success; it is unacceptable to blame and punish entrepreneurial and creative employees for the failures just because they try to introduce changes in the organisation. Relying on a system of penalties for failures definitely weakens the creative atmosphere within the organisation. In turn, rewarding employees should be based not only on the methods used so far but also on the risk taken which was necessary to introduce new solutions. By implementing a mechanism for creating, developing, and promoting new ideas in the enterprise, it is possible to respond more quickly to the market signals and challenges (Strychalska-Rudzewicz, 2009, pp. 1207-1209). The best methods or techniques will not guarantee the intended results in the production or provision of services. The basis for creating innovative and frugal solutions is the commitment of the staff.

\section{Conclusion}

Today, any innovative venture should be based on a frugal mindset. In other words, representatives of businesses, both large and small, must learn to use all the resources that are within their reach. This may involve a recombination of existing materials, knowledge, and skills in a creative way, or adapting existing technologies to deal with a crisis.

In order to better understand and be able to search for opportunities and threats emerging in this environment, as well as to broaden perspectives, the thinking of the staff hired by the company should be creative, inventive, and lateral (including new ways of looking at things). One of the characteristic features of the creative process in the field of frugal innovations, one that makes it so crucial, is that it requires not only knowledge in a specific area but also the proper willingness, the ability to ask questions and to avoid limiting ourselves to the existing, available knowledge. Creativity requires a certain reflection on the essence of the problem, a level of commitment as well as increased trust and responsibility.

Taking into account all the aforementioned arguments, it can be said, again, that creativity is one of the most important sources of frugal innovations. For this reason, it is necessary to invest in staff and create appropriate conditions for them in the company, thanks to which each employee will be able to notice current problems and try to solve them creatively, ultimately leading to the implementation of a number of innovative solutions that benefit the company, the natural environment, and society as a whole. 


\section{References}

1. A conceptual analysis of foundations, trends and relevant potentials in the field of frugal innovation (for Europe) (2016). Interim report for the project "study on frugal innovation and reengineering of traditional techniques" - Study, Directorate-General for Research and Innovation, Fraunhofer ISI, Nesta. European Commission.

2. Amabile, T. (1998). How to kill creativity. Harvard Business Review, 76, no. 5.

3. Armstrong, M. (1997). Jak być lepszym menedżerem. Warszawa: Dom Wydawniczy ABC.

4. Bal-Woźniak, T. (2010). Warunki usprawnienia zarządzania innowacyjnością w kontekście współczesnych wyzwań. In: S. Lachiewicz, A. Zakrzewska-Bielawska (eds.), Zarządzanie wiedza i innowacjami we współczesnych organizacjach. Łódź: Wydawnictwo Politechniki Łódzkiej.

5. Baruk, J. (2006). Zarzadzanie wiedza i innowacjami. Toruń: Wydawnictwo Adam Marszałek.

6. Bencsik, A., Machová, R., Tóth, Z. (2016). Cheap and clever - symbiosis of frugal innovation and knowledge management. Problems and Perspectives in Management, vol. 14(1).

7. Bogdanienko, J., Haffer, M., Popławski, W. (2004). Innowacyjność przedsiębiorstw. Toruń: Wydawnictwo Naukowe Uniwersytetu Mikołaja Kopernika.

8. Bontoux, L., Bengtsson, D. (2015). 2035 Paths towards a sustainable EU economy Sustainable transitions and the potential of eco-innovation for jobs and economic development in EU eco-industries 2035. Publications Office of the European Union.

9. Chyba, Z. (2014). Porównanie wybranych źródeł innowacji w przedsiębiorstwie. Krakowskie Studia Małopolskie, nr 19.

10. Francik, A., Kosała, M. (2011). Teoretyczne aspekty procesów innowacyjnych w organizacjach. Zeszyty Naukowe Uniwersytetu Ekonomicznego w Krakowie, nr 866.

11. Grudzewski, W.M., Hejduk, I.K., Sankowska, A., Wańtuchowicz, M. (2010). Sustainability $w$ biznesie czyli przedsiębiorstwo przyszłości. Zmiany paradygmatow $i$ koncepcji zarzadzania. Warszawa: Poltext.

12. https://includeplatform.net/blog/frugal-innovation-during-the-covid-19-crisis-examplesfrom-east-africa/, 29.08.2020.

13. https://www.roberthalf.com/blog/management-tips/7-elements-of-a-highly-creative-workenvironment, 28.08.2020.

14. Intelligent Economies: AI's transformation of industries and society (2018). A report from The Economist Intelligence Unit. The Economist Intelligence Unit Limited.

15. Jung, B. (2010). Kreatywne gospodarki i „kreatywna klasa”. Otoczenie mediów ery Web 2.0. In: B. Jung (ed.), Wokół mediów ery Web 2.0. Warszawa: Wydawnictwa Akademickie i Profesjonalne. 
16. Kaliszczak, L. (2013). Kreatywność i innowacyjność w kształtowaniu wartości rynkowej oraz przewagi konkurencyjnej przedsiębiorstw. Przedsiębiorstwo i region, $n r$ 5. Rzeszów: Wydawnictwo Uniwersytetu Rzeszowskiego.

17. Kampylis, P., Berki, E. (2014). Nurturing creative thinking. International Academy of Education. UNESCO.

18. Kaz, M., Ilina, T., Medvedev, G.A. (2019). Global Economics and Management: Transition to Economy 4.0 Prospects of Fundamental Science Development International Conference 2018 (PFSD 2018): Economics and Management Session. Springer International Publishing.

19. Khan, R. (2016). How Frugal Innovation Promotes Social Sustainability. Sustainability, vol. $8(10)$.

20. OECD (1999). The Knowledge-Based Economy: A set of facts and figures. Paris.

21. Penc, J. (1999). Innowacje i zmiany w firmie. Warszawa: Agencja Wydawnicza Placet.

22. Pomykalski, A. (2001). Innowacje. Łódź: Politechnika Łódzka.

23. Radjou, N., Prabhu, J. (2014). Frugal Innovation: How to Do More with Less, 1st ed. London: Profile Books Ltd.

24. Stein, M.I. (1953). Creativity and culture. The Journal of Psychology, 36.

25. Strychalska-Rudzewicz, A. (2009). Kulturowe determinanty innowacyjności przedsiębiorstw. In: M. Czerska, H. Czubasiewicz (eds.). Społeczne uwarunkowania sukcesu organizacji. Sopot: Prace i Materiały Wydziału Zarządzania Uniwersytetu Gdańskiego.

26. Szara, K. (2014). Kreatywność a innowacyjność w działalności podkarpackich przedsiębiorców. Zeszyty Naukowe MWSE w Tarnowie, $n r$ 1(24).

27. Szmidt, K.J. (2013). Trening kreatywności. Gliwice: Helion.

28. Tiwari, R., Herstatt, C. (2012). India - A Lead Market for Frugal Innovations? Extending the Lead Market Theory to Emerging Economies. Working Paper No. 67. Institute for Technology and Innovation Management. Hamburg: Hamburg University of Technology.

29. Weyrauch, T., Herstatt, C. (2016). What is frugal innvation? Three defining criteria. Journal of Frugal Innovation, 2(1).

30. Zeschky, M., Widenmayer, B., Gassmann, O. (2011). Frugal Innovation in Emerging Markets: The Case of Mettler Toledo. Research-Technology Management, 54. 